\title{
Some Jewish Folklore from Jerusalem.
}

\section{Gaster}

To cite this article: M. Gaster (1904) Some Jewish Folklore from Jerusalem., Folklore, 15:2, 186-194, DOI: 10.1080/0015587X.1904.9719400

To link to this article: http://dx.doi.org/10.1080/0015587X.1904.9719400

$$
\text { 曲 Published online: } 06 \text { Feb } 2012 .
$$

Submit your article to this journal ๘

Џlll Article views: 1

Q View related articles $\asymp$ 
Some Jewish Folklore from Jerusalem.

(Read at Meeting, I th December, 1903. Ante, p. 2.)

THE Jews here have various methods closely resembling those of the Outer Islands of the Hebrides for "dodging " the Powers of Evil. For example, when a sick person seems unable to die and unlikely to recover, they pray for him under a different name, using Isaac, for instance, if his name happens to be Benjamin, apparently on the theory that God will know who is prayed for, whereas it will perplex the Evil Spirit who has brought about his condition, so that when he enters the sick chamber to take possession of Isaac, he starts back in astonishment to find his old friend Benjamin, who is thus enabled to escape.

The story is current in Jerusalem that a certain Jew who had lost six wives in childbirth was anxious to propitiate the $A$ ngel of Death. When about to marry for the seventh time he bought a cow and tied her up outside his window, and then the marriage ceremony was performed between them, the ring being placed upon her horn, the contract of marriage being drawn up in due form. This accomplished, he proceeded to matrimony with the girl of his choice, the cow was killed, her flesh distributed among the poor, and the pair lived happy ever after and had a large family.

Many curious customs are connected with childbirth. The woman is at this time particularly exposed to the jealousy of Lilith and other "Not-good Ones," and in some households it is usual to attach verses from the Psalms to such spots as the Evil Ones would have to pass in gaining access to her: the window, chimney, door, and the curtains to her bed. It is, however, objected among the ultra-pious that it is wanting in respect to the Psalms to introduce them into a room ceremonially defiled.

The destroying angel on taking the life of a Jew, washes his knife in the water of six houses, so that on the occasion of a death every drop of water has to be thrown away in three houses, right and left; a serious loss where every pint of water has its definite 
money value. Last year (1901), when a water famine hrought disease and death in its train, the custom became a really important social question.

Nail-parings (as in the Highlands) must be hidden in the cracks of the house-walls or burnt. Sometimes a Jewish woman will serve her hair or nail-parings in a pudding to be eaten by her husband, in order to increase his affection. Nails should be cut early in the week so as not to begin to grow on the Sabbath.

It is said that when a child dies, a piece of worsted, marked with the measures of his favourite playfellows, is put into his coffin, so that he may not be lonely, and so be tempted to call upon them to follow.

The "conversionists," as the Jews call the missionaries, allege that the Jews believe in Moon-worship. As a matter of fact they have a certain ceremonial upon seeing the moon at seven days old, and in the open air, but it is fair to remember that they have special blessings not only for this but for many occasions; on drinking wine, on smelling sweet odours, on seeing the rainbow, \&c, \&c. On first seeing the new moon under the prescribed conditions, the Jew stands with one foot upon the other, and says, "Blessed be He who formed thee, blessed be thy Maker, blessed be thy Creator, blessed be thy Possessor." Then he skips three times, and adds, "Fear and drend shall fall upon them by the greatness of thy arm, they shall be as still as a stone"; which he repeats twice. Some allege that he also repeats it backwards; then he concludes with "David, the King of Israel, liveth and existeth." After which he must salute the person he first meets.

The new moon, as with us, must not be looked at through the window. A reasonable explanation has been suggested in the fact mentioned in the Mishneh, that the evidence of a witness as to the appearance of the moon would not be taken if he first saw it through glass or reflected in water.

The Indulca, or Indulco, is a form of exorcism still practised in Jerusalem by the Spanish Jews (Sephardim) in extreme cases of such disease (madness, epilepsy, barrenness, loss of young children, \&rc.) as is regarded as incurable by ordinary methods. There are two classes of Indulca, the great and the small.

The small is thus practised. The patient's room and the adjoining habitations are cleared out, cleaned, whitewashed, and decurated. All holy books are removed, and the patient is for- 
bidden to pray, to recite Holy Scripture, or to mention sacred words or names. The witch is then called in, and she prepares a little wheat, barley, salt, water, milk, honey, four or six eggs, and some sweetmeats or sugar. At midnight she mixes all these ingredients together, and scatters some of the mixture round the sick-bed, on the threshold, and in the four corners of the room, reciting in a whisper as follows :

"My Lords, I beseech you to pity, compassionate, and have mercy upon the soul (or life) of your servant (or slave, if it be a woman) the patient (giving the name) the son (or daughter) of your maid (giving the mother's name) and overlook his (or her) trespass; and if he (or she) have sinned, and done any evil to you, forgive and pardon his (or her) sins; give him (or her) life, and restore his (or her) health and strength. (If to a barren woman, she adds), Open her womb and restore to her the fruits of her body. (If to those who lose young children), Give life to their sons and daughters, and let this honey (or sugar) be to sweeten your mouths and palates, the wheat and barley to feed your cattle and sheep, and the water and salt to establish peace, friendship, love, brotherhood, an everlasting covenant of salt between us and you."

Here she breaks the eggs and pours the same in the aforementioned places, kneels and prostrates herself, kisses the ground several times, and proceeds with these words :

"Here I offer you life for life, in order that ye may restore the life 1 of this patient." 'This is continued or repeated for two more successive nights, and if the case is obstinate, for even seven or nine nights in succession.

If the patient cannot afford the necessary expense, or if the neighbours decline to leave the adjoining rooms, the witch may think it sufficient to go to a cistern, bath, or tannery, and there pour a little salt and water and pray as before, and say, "Behold water and salt to be a covenant of peace between us."

The Great Indulca only differs in being prolonged forty-five nights, the patient being required to dress in rich white garments, and the room to be handsomely decorated and well lit with wax candles. In addition to the ingredients above prescribed, there must be many savoury dishes, fruits, and spices.

The great influence upon which the Jews of Palestine depend

1 Or his reason, or whatcver may be the alliction in question. 
Plate IV,

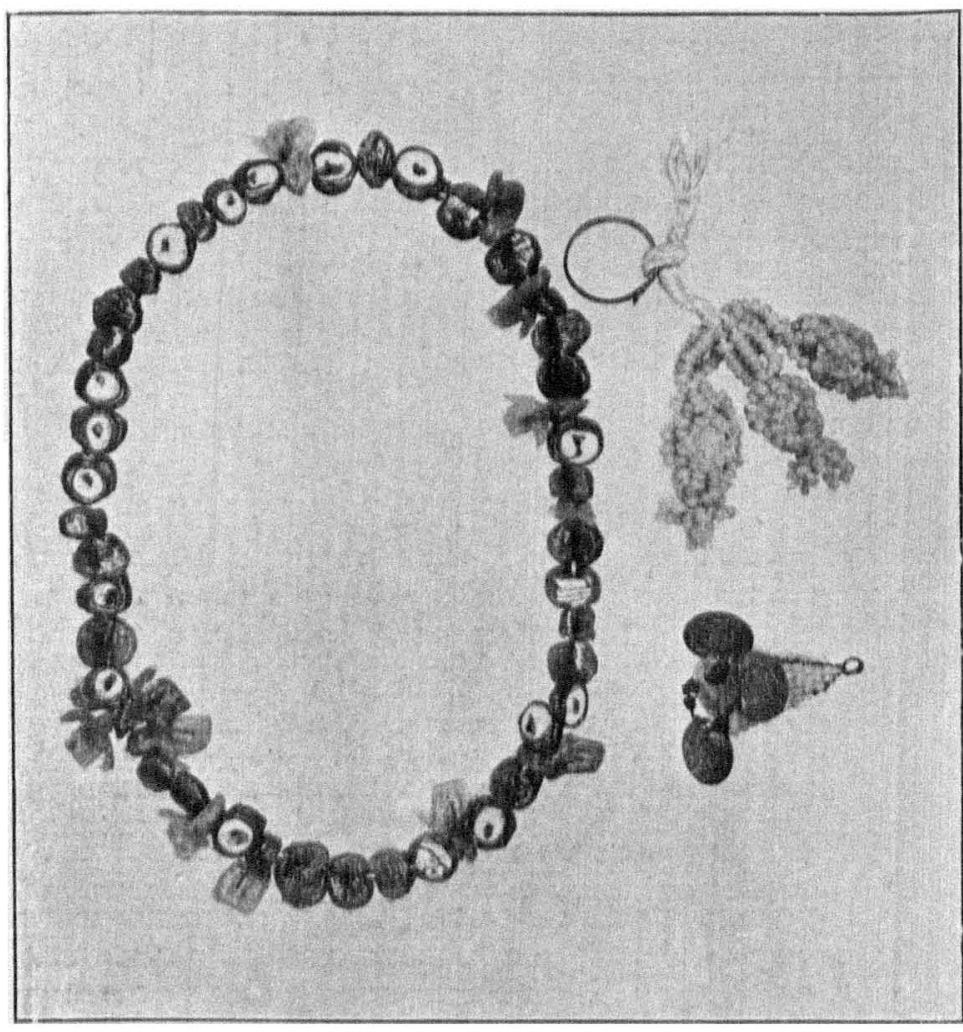

NECKLACE OF BLUE BEADS AND TWO EYE CHARMS.

(From Jerusalem.)

To face p. 189. 
for preservation from the Evil Eye is the presence of the Hand of Might, a superstition about which this Society is undoubtedly fully informed, as it is widespread, both in time and space. In Egypt the hand, in the form of a gold charm, was given to me as a Moslem symbol, and as representing the hand of Fat'ma, but the Moslems of Jerusalem relegate the superstition to the sons of Isaac, and profess to know nothing whatever about it. Here it is worn by men, women, and children, and it decorates the front of almost every Jewish house, sometimes merely as if the hand of a man had been dipped in blue paint and impressed upon the lintel, sometimes so large as to be literally visible across an intervening valley. Women and girls are adorned with bracelets and necklaces entirely composed of hands, and it is the favourite form of the Jewish wedding-ring.

The colour is always, if possible, blue, a point upon which I have failed to obtain any local information other than the hint conveyed in the following circumstance. Referring to Caliban's description of his mother, the witch Sycorax, as that "blue-eyed hag," I ventured to quote the usual gloss that it was an early misprint for " blear-eyed," upon which the well-known Palestinian scholar, the Rev. E. Hanauer, who was present, suggested that according to Jerusalem ideas such an emendation was unnecessary, as blue was the colour of the Evil Eye, and a mother would dread notice of her children by a blue-eyed stranger more than that of any other. As in parts of Northern Europe the same superstition would apply to the black eye, is it not possible that in both cases the object of greatest dread is the stranger? The Frank in the one case, the Southerner in the other.' The horses, camels, and donkeys wear blue necklaces, sometimes a string of beads, sametines a collar elaborately embroidered in beads, or at the least a large blue ornament hanging from the neck. The children have charms on their heads made of a bit of alum stitched into blue cloth or encased in blue beads, and the notion of blue is so widespread that when I ordered some baskets to be woven for me, even in the purely "Christian" village of Ramallah, a few blue beads were carefully fastened to each.

Should the Hand of Might, and the necklaces, and the alum,

' [Cf. vol, xill, pp. 202, 337, - En.]

- Is this an analogy with the English superatition of wearing camphor in the spring ? 
and the blue beads fail of their object, there are still charms in the possession of the Rabbis which may avert ultimate catastrophe. They are often suspended in a bag round the neck of the afficted person. The following is one in common use. It will be seen by the enumeration that the mixing may be involuntary, and occasioned even by one's nearest and dearest. The adjuration preceding it is pronounced as the patient receives and is invested with the cnarm.

I adjure you, all kinds of evil eyes, a black eye, blue eye, hazel eye, yellow eye, shurt eye, long eye, round eye, broad eye, narrow eye, straight eye, hollow eye, deep eyc, projecting eye, male eye, female eye, eye of wife and husband, eye of a woman and her daughter, eye of her relatives, eye of a bachelor, eye of an sid man, eye of an old woman, eye of a virgin, eye of a maiden, eye of a widow, eye of a married woman, eye of a divorced woman, all surts of evil eyes in the world, which looked and spake with an evil concerning $\mathrm{N}$.

I command and adjure you by the Most Holy, Mighty, and High Eye, the only Eye, the white Eye, the right Eye, the open Eye, the most careful and compassionate Eye, the Eye that never slumbers nor slecps, the Eye to which all eyes are subjected, the wakeful Eye that preserveth Israel, as it is written in Psalm cxxi. 4: "Behold, He that keepeth Israel shall neither slumber nor sleep," and also as it is written, "The Eye of the Lord is upon them that fear Him, to those who trust in IIis goodness." With that Most Iigh Eye, I cammand and adjure you, all kinds of evil eyes, to depart, and to be rooted out and fee away to a distance, from $\mathbf{N}$. and from all his household, and that you shall have no power whatever on N., neither by day nor by night, neithes when awake nor in dreams, nor on any number of his two hundred and fortyeight limbs, nor on any of his four hundred and five veins, from this day forth Amen.

\section{The Charm.}

Nezah Selah. "Thou art my hiding place, Thou shalt preserve me from trouble : Thou shalt compass me about with songs of deliverance." Selah.

"Ie that dwelleth in the secret place of the Most II igh shall abide under the shadow of the Almighty."

Adam, Abraham, Isaac, and Jacob.

linter Sini, Sansen, and Samenglorf.

Thou shalt not suffer a witch to live.

Thou shalt not suffer a witch to live.

Thou shalt not suffer a witch to llve.

In the centre Psalm cxxi, is printed.

The longer necklace figured on Plate $\mathrm{V}$. is of a kind much treasured by Yemenite Jews, and never sold unless when, as now, 
Plate V.

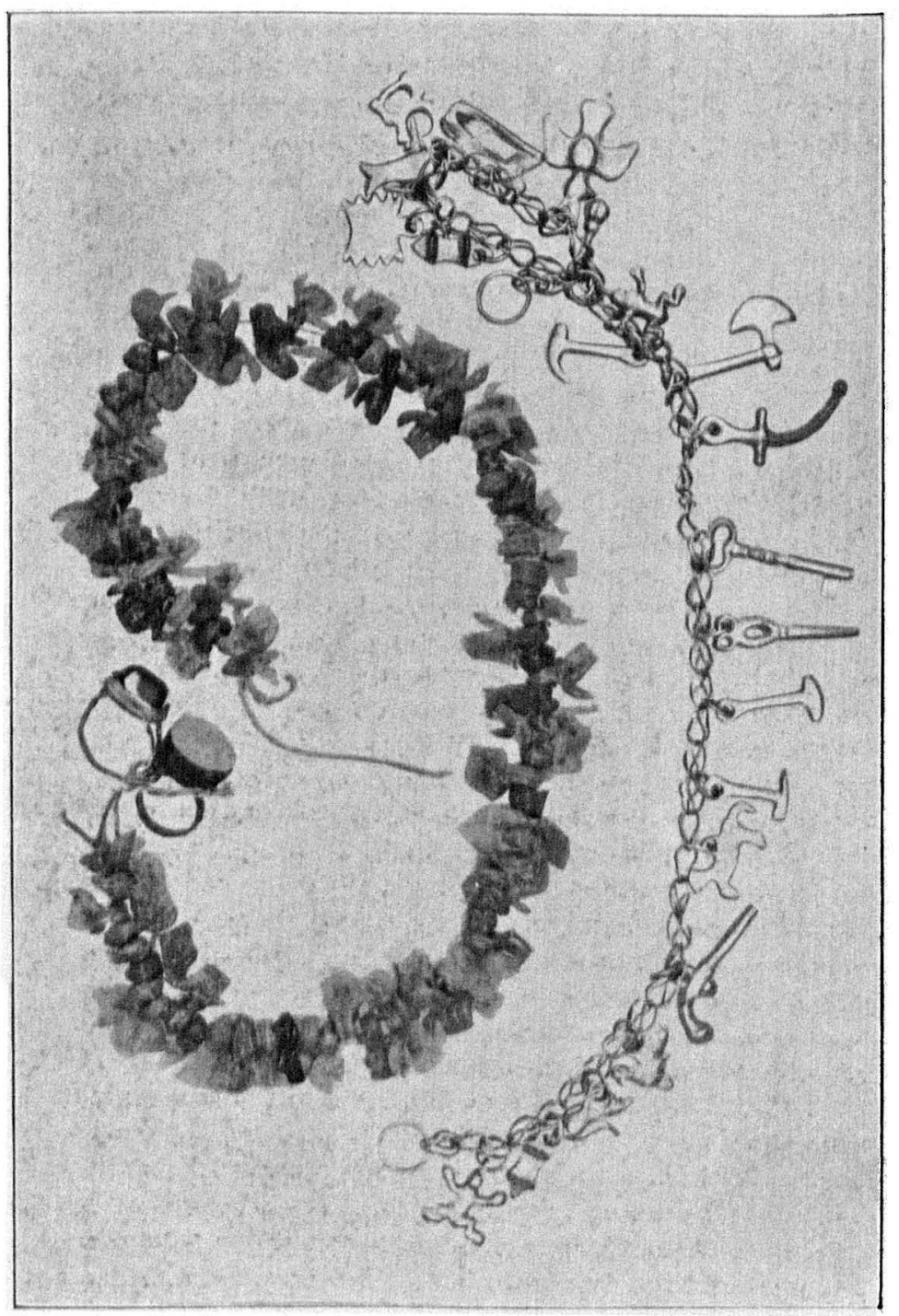

CHARM NECKLACES FROM JERUSALEM.

To face p. 191 . 
there is great poverty among them. The ornaments are all objects of domestic or every-day use, and the necklace, worn by a housewife, secures the peacenble possession of all her ordinary belongings. $\Lambda$ some are not quite easy to distinguish, I subjoin a list as given meby a Jew.

t. Male frog. 2. Shoe. 3. Comb. ('These are generally made of wood.) 4. Stove (for roasting coffee). 5. Lock. 6. Dog. 7. Pigeon. 8. Pestle (for coffee). 9. Hammer. io. Axe. II. Sabre. 12. Key. I3. Scissors. I4, Hammer (for tent-pegs). I5. Pickaxe (used mainly for extracting the roots of trees long ago cut down, to which the people are now reduced for fuel). 16. Camel. 17. Pistol. I8. Hen. 19. Coffee-pot. 20. Shoe. 21. Frog.

The exact nature of the superstition connected with the frog I have not been able to ascertain, and fancy it may be of a nature not easily imparted to a lady inquirer. The frogs are used in pairs, male and female, and those I have seen were always in the possession of Jews from Yemen in Arabia, great numbers of whom are now living near Jerusalem in what is known as the Box Colony, being built mainly of the tin boxes in which petroleum is brought from Russia and Galicia. It has been suggested, but I offer it only as a suggestion, that as the frog is associated with evil, it is separated at both ends from the harmless objects of domestic life by a shoe, which, though not evil, is an object of contempt. Hence the saying that you must not speak to a man of his shoes or his wife!

The charms figured on Plate IV. are both against eye-trouble, the most prevalent of all diseases in this country. They are hung round the head so as to hang over the afflicted eye; the green for severe cases, the brown for temporary inflammation.

The children's charms, alum in an ornamental network of beads, are worn by Moslems and Christians as well as by Jews.

A. Goodrich-Freer.

\section{The following is a description of the devicas impressed an the metal (silver) amulet also exhibited. (Seep. 2.)}

I. Obverse.-A picture of Rachel's Tomb with the words "Tomb of Rachel" underneath, and as an encircling legend the following prayer: "May it be pleasing in Thy sight, $\mathrm{O}$ my God 
and the God of my fathers, to preserve this child from the evil eye, and sickness and all misfortune."

II. Reverse.-The letter $\Pi=\mathrm{He}$, for the name "Jehovah,' enclosing two hands symbolic of the priestly blessing (Numbers vi. 24). The central inscription is: "Bless thee, $\pi=$ (Jehovah') and keep thee," and underneath the word "Jerusalem." The encircling legend is the blessing of Joseph (Gen. xlix. 22): "Joseph is a fruitful bough, even a fruitful bough by a spring." "Ain." Possibly the charm was made to be worn by a child named Joseph.

Rachel's Tomb is on the road to Bethlehem, and this is a very good likeness of it. It will be remembered that she died in childbirth, and as her tomb is visible from Bethlehem one the better understands the reference to "Rachel weeping for her children." The tomb (restored by Sir Moses Montefiore) is of great antiquity, and on certain days one sees it surrounded by women, Jews, Christians, and Moslems, many of whom are offering prayers and vows in the hope of becoming mothers, others praying for the welfare of young children.

A. G, F.

\section{Notes on Miss Freer's Paper.}

Ir is a somewhat dangerous procedure to call religious ceremonies "superstitions," for then there will be no possible definition for "superstition." The outgrowth from or beyond the regular form of worship and the addition of principles not recognised by the ruling faith would appear to me to cover the ground, if we carefully abstain from confusing the one with the other. The so-called worship of the moon (p. 187 ) is an example in point. There is not the remotest connection between the regular form of prayer to God as Creator of the moon and "superstition," for He is praised as in every other case and as on many other occasions. The renewal of the moon at the end of its evolution and complete disappearance is taken as an occasion for uttering a prayer, which is not by a single word directed to the moon. It must be remembered that the revolution of the moon is the basis of the religious calendar, hence the immense importance attached to its appearance and to the exact notation of that period. Connected with this calendaristic importance is the 
mystıcal Messianic idea; hence the verse "David liveth." I can not enter into a detailed discussion of this complicated question, beyond that it has nothing whatsoever to do with "superstition," and it does not contain a single item of superstitious belief or practice.

The change of the name of a patient is part of the general system of ascribing the most potent value to a name. Readers of FolkLore have had the opportunity of studying the extremely suggestive article by Mr. Clodd on Rumpelstiltzchen, and on the mystical and symbolical value attached to names. The same idea is expressed in the change of the name of the patient, which is equivalent to a re-birth, and is expected to save the patient by endowing him with a new life-entity, not by deceiving the evil spirit who is his enemy.

The ceremony described as an "exorcism" is merely a "propitiation" or "disenchantment," for it does not drive out any malignant spirit. Nor can the person who pronounces the "disenchantment " formula be called a "witch," for she does not refer in her practice to any connection with the "Evil Ones." !

The Evil Eye formula is borrowed from the Arabs. Miss Freer has evidently taken it from the Jews who came from Yemen some thirty years ago after a terrible persecution they suffered at the hands of the Arabs when occupying Sanaa after their fight against the Turks. An absolutely identical formula has been published by me from Rumanian sources, which prove the extreme antiquity of this special form of "disenchantment." It occurs also with slight variations in Assyrian tablets, and has been published by Lenormant and since then often by others.

The reference to Joseph in the amulet has a history of its own. It rests ultimately on the combination of two separate sets of ideas. In the blessing of Jacob (Genesis xlviii. I6), according to an old traditional interpretation of the Hebrew words, the

[' It ts not expressly stated who are the "My Lords" whom the witch addresses, but their nature may be inferred from the prohibition to pray, mention holy names, or recite Scripture. To serve other gods is of the very essence of the witch's craft, so that Miss Goodrich Freer's terminology here seems perfectly correct. But Dr. Gaster's criticism of her application of the word "exorcism" to the ceremony seems justified. Exorcism is the banlshment of pirits by the power of other mightier spirits ; the ceremony in question consists merely of prayer to, and propitiation of, the haunting spirits themselves.-ED.] VOL. XV. 
translation reads, not as in the Authorised or Revised, "let them grow into a multitude," speaking of Joseph's children, but "let them multiply like the fishes," and it is further asserted that the evil eye has no power over the fishes, for they are protected by the sheen of the water. In every case where the effect of the evil eye is to be averted Joseph and this blessing are invoked, with the hope that the same result may happen now also to the aflicted one. It is a case of symbolical substitution.

The "hand" is an universal Oriental and Occidental sign for averting the influence of the evil eye (v. Jahn and Elworthy). The protection of a woman in childbirth against the attacks of Lilith and the formulas used on that occasion have been fully treated by me in the "Charm of Two Thousand Years," published in Folk-Lore vol. xi., pp. 129.

M. Gaster.

\section{Pembrokeshire Notes.}

(Communicated through Mr. W. P. Merrick).

\section{An Old South Pembrokeshire Harvest Custom.}

"Ir's none used now, but when I were a young maid the farms was a deal bigger, and more corn grown; there would be four and five men kep' on a farm, beside day-labourers. There must be a foreman, maybe the farmer's eldest son, maybe a hired man; and he must take the lead in all things in the field. In harvest the foreman cut at the head, and the rest, reapers and binders, must keep time along with him. With neighbour-farms it would be a race, whiche one would first finish cutting corn. The foreman would plan it out to finish in some cornel, not for to be seen by the rest farms; then with the last handful he would make a wrach-leastways two wrachs. We called it by the Welsh name; I don't know, is there an English?" (I suggested "wreath," "posy" ") "No, not that ; it's just a cry the Welsh have when they have finished a thing - they will say, 'Wrach ! wrach!' Now the foreman he must lay his wrach on the breid (swath) of the 